\title{
Preparation of milk protein concentrates by ultrafiltration and continuous diafiltration: Effect of process design on overall efficiency
}

\author{
C. Gavazzi-April, ${ }^{*}$ S. Benoit, ${ }^{*}$ A. Doyen, ${ }^{*}$ M. Britten, $\dagger$ and Y. Pouliot*1 \\ *STELA Dairy Research Center, Institute of Nutrition and Functional Foods, Department of Food Sciences, Université Laval, Québec, QC, \\ Canada, G1V 0A6 \\ †St-Hyacinthe Research and Development Centre, Agriculture and Agri-Food Canada, St-Hyacinthe, QC, Canada, J2S 8E3
}

\begin{abstract}
High-milk-protein concentrates $(>80 \%$ on a dry weight basis) are typically produced by ultrafiltration (UF) with constant-volume diafiltration (DF). To maximize protein retention at a commercial scale, polymeric spiral-wound UF membranes with a molecular weight cut-off (MWCO) of $10 \mathrm{kDa}$ are commonly used. Flux decline and membrane fouling during UF have been studied extensively and the selection of an optimal UF-DF sequence is expected to have a considerable effect on both the process efficiency and the volumes of by-products generated. The objective of this study was to characterize the performance of the UF-DF process by evaluating permeate flux decline, fouling resistance, energy and water consumption, and retentate composition as a function of MWCO (10 and $50 \mathrm{kDa})$ and UFDF sequence $[3.5 \times-2$ diavolumes (DV) and $5 \times-0.8 \mathrm{DV}]$. The UF-DF experiments were performed on pasteurized skim milk using a pilot-scale filtration system operated at $50^{\circ} \mathrm{C}$ under a constant transmembrane pressure of $465 \mathrm{kPa}$. The results showed that MWCO had no effect on permeate flux for the same UF-DF sequence. Irreversible resistance was also similar for both sequences, whatever the MWCO, suggesting that soluble protein deposition within the pores is similar for all conditions. Despite lower permeate fluxes and greater reversible resistance for the $5 \times-0.8 \mathrm{DV}$ sequence, the overall energy consumption of the 2 UF-DF sequences was similar. However, the $3.5 \times-2 \mathrm{DV}$ sequence required more water for $\mathrm{DF}$ and generated larger volumes of permeate to be processed, which will require more membrane area and lead to greater environmental impact. A comparative life cycle assessment should however be performed to confirm which sequence has the lowest environmental impact.
\end{abstract}

Received January 11, 2018.

Accepted July 9, 2018.

${ }^{1}$ Corresponding author: Yves.Pouliot@fsaa.ulaval.ca
Key words: high milk protein concentrate, ultrafiltration, constant-volume diafiltration, process efficiency, energy consumption

\section{INTRODUCTION}

Skim milk UF is a common pressure-driven membrane process in the dairy industry that concentrates milk proteins by partially removing the water, lactose, salts, peptides, and other solutes (Cheryan, 1998). The benefits of concentrating milk proteins using membrane processes include retention of high concentrations of protein (de Boer, 2014) and the potential for a less energy-intensive process, compared with evaporation or drying (Cheryan, 1998). Today, UF concentrates are mainly used to improve the efficiency of cheesemaking by increasing cheese milk protein concentration (Govindasamy-Lucey et al., 2005; Guinee et al., 2006). In cheese processing, pre-concentration of milk by UF maximizes the capacity of the equipment, reduces the amount of rennet and salt needed, provides better control of the composition of the curd, and increases cheese yields (Rosenberg, 1995; Guinee et al., 2006; Pouliot, 2008; Heino et al., 2010).

In addition to pre-concentrating milk for cheese making, UF is also widely used to produce milk protein concentrates (MPC; Rosenberg, 1995; Pouliot, 2008; de Boer, 2014). High protein-containing MPC (over $80 \%$ total protein on a dry weight basis) are typically produced by UF in combination with diafiltration (DF), which introduces water to the feed at the same volumetric flow rate as that of the permeate (Asbi and Cheryan, 1992; Lapointe-Vignola and Fondation de Technologie Laitière du Québec Inc., 2002). Diafiltration is introduced into the process when the feed concentration reaches a certain level, and its purpose is to overcome the high rise in viscosity. When concentrating skim milk, the threshold for starting DF should be selected so that the highest possible protein concentration is achieved while membrane fouling and water consumption are minimized (Li et al., 2017). Despite the many advantages of UF for the production of 
MPC and UF retentates, the application of membrane processes for producing high-protein-containing MPC has its limitations: the main one is a severe reduction in permeation fluxes (Li et al., 2017). Flux decline resulting from concentration polarization and fouling during skim milk UF at low concentration factor (CF) has been studied extensively (Bacchin et al., 2006; Shi et al., 2014; Ng et al., 2017). However, selecting an optimal UF-DF sequence to improve the process efficiency for high solids concentration has received little attention.

In the dairy industry, polymeric spiral-wound membranes are commonly used for concentration processes because of their low investment and replacement costs (Meyer et al., 2015). A molecular weight cut-off (MWCO) of $10 \mathrm{kDa}$ is often selected to maximize protein retention (Hu and Dickson, 2015). However, MWCO alone is not sufficient to predict process performance as feed concentration, applied pressure, and fluid composition may significantly affect performance (de Boer, 2014). Moreover, MWCO does not provide much insight into the selectivity of the membrane for molecules with a molecular weight lower than the MWCO (Meireles et al., 1995). Meireles et al. (1991) demonstrated that after a few minutes into the filtration process, the apparent structure of the membrane acquires certain properties depending on the size of the molecules in the solution (Meireles et al., 1991). However, no such study has been conducted with a more complex fluid such as milk.

Besides membrane MWCO, various operating parameters can have a direct and significant influence on the efficiency of the UF process. Process efficiency can also be characterized by the permeation flux ( $\mathrm{J}$, $\mathrm{kg} / \mathrm{h} \cdot \mathrm{m}^{2}$ ), which refers to the mass flow of permeate through the filtration membrane $(\mathrm{kg} / \mathrm{h})$ per unit area of membrane $\left(\mathrm{m}^{2}\right.$; Bazinet and Castaigne, 2011). Of the main challenges faced by membrane filtration processes, the need to minimize water use is one of the most important (Pouliot, 2008). Likewise, membrane processes generate high volumes of permeate that is of little commercial value, but must be treated to remove lactose and minerals (Adams et al., 2013). Therefore, reducing both water use and the production of byproducts are key factors for improving the efficiency of filtration processes.

Moreover, energy efficiency refers to the optimization of a system's energy consumption (i.e., the reduction of the energy cost to provide a product or service). From an industrial point of view, it typically involves reducing the energy intensity of the equipment, adopting more efficient technologies or reducing energy losses in the system. Energy efficiency during UF of milk has received limited attention in recent years. Rinaldoni et al. (2009) showed that most of the energy consumption during UF of milk occurs in the thermal process and not in the mechanical pumping of the fluid. Similarly, Méthot-Hains et al. (2016) demonstrated that, despite lower thermal energy consumption at $10^{\circ} \mathrm{C}$ than at $50^{\circ} \mathrm{C}$ during skim milk UF using a pilot-scale unit, producing a $\mathrm{CF} 3.6 \times$ milk retentate at $10^{\circ} \mathrm{C}$ would require 2.3 times more pumping energy than operating at $50^{\circ} \mathrm{C}$. According to that study, skim milk UF would be the most efficient at low transmembrane pressure (TMP; $465 \mathrm{kPa})$ and high temperature $\left(50^{\circ} \mathrm{C}\right.$; Méthot-Hains et al., 2016).

Improving efficiency during UF-DF of high-concentration milk solutions can be achieved by maximizing the permeate fluxes and protein retention while minimizing fouling and the amount of water required for DF. The objective of this study was to analyze the effect of membrane MWCO (10 and $50 \mathrm{kDa})$ and UFDF sequence [3.5 $\times-2$ diavolumes $(\mathbf{D V})$ and $5 \times-0.8 \mathrm{DV}]$ on the performance (permeation flux decline, hydraulic resistance, protein rejection, and water and energy consumption) of a skim milk UF-DF process.

\section{MATERIALS AND METHODS}

\section{UF System and Membrane Conditioning Process}

The UF-DF experiments were performed on a pilotscale filtration unit (GEA NIRO, Hudson, WI) as described previously by Méthot-Hains et al. (2016). The 60-L stainless steel feed tank was connected to a positive displacement feed pump (D/G-10, 576V, $5 \mathrm{HP}$ Wanner International Ltd., Minneapolis, MN), powering the whole unit. One pressure gauge was located at each end of the membrane module to monitor the transmembrane pressure. The system was equipped with a spiral-wound polyethersulfone (PES) UF membrane with a MWCO of $10 \mathrm{kDa}$ (model ST-3B-2540M) or $50 \mathrm{kDa}$ (model MQ-3B-2540M, Synder Filtration Inc., Vacaville, CA). Each UF element was $97 \mathrm{~cm}$ long with an outer diameter of $6.35 \mathrm{~cm}$ and a $1.17-\mathrm{mm}$ spacer thickness. Total membrane surface area was $2.04 \mathrm{~m}^{2}$. The temperature was controlled throughout the experiment by a heat exchanger located in the feed section and a thermocouple probe (model FD02, Pyromation, Fort Wayne, IN). Prior to filtration experiments, UF membranes were conditioned (Membra-Chlor 310, pH 10.5, Ecolab Inc., Laval, QC, Canada) at $50^{\circ} \mathrm{C}$ for 10 min. The membranes were then rinsed with tap water to a neutral $\mathrm{pH}$. The mean initial water permeate flux was measured at TMP $465 \mathrm{kPa}$ and $50^{\circ} \mathrm{C}$ for each UF membrane for further calculation of membrane resistance values. 


\section{UF-DF Experiments}

Pasteurized skim milk was purchased from a local dairy manufacturer and stored at $4^{\circ} \mathrm{C}$ until use. Three $340 \mathrm{~kg}$ batches were equally divided into $487.5 \mathrm{~kg}$ batches, one for each of the experimental conditions $(3.5 \times-2 \mathrm{DV}$ and $5 \times-0.8 \mathrm{DV}$ with the 10 and $50 \mathrm{kDa}$ UF membranes). These UF-DF combinations were established to reach a final protein content of approximately $80 \%$ dry weight. The UF system was operated in batch mode at $50^{\circ} \mathrm{C}$, under an optimal and constant TMP of $465 \mathrm{kPa}$, as previously observed by MéthotHains et al. (2016). A tubular heat exchanger was used to heat and maintain skim milk at $50^{\circ} \mathrm{C}$ for all UF-DF experiments. Skim milk was ultrafiltered until a CF of $3.5 \times$ or $5 \times$ was reached, as described by Méthot-Hains et al. (2016). Once the target CF was reached, DF was carried out by gradually adding 2 or $0.8 \mathrm{DV}$ of tap water $\left(50^{\circ} \mathrm{C}\right)$ to the retentate while keeping its volume constant. Samples of the initial skim milk, the permeate produced at the end of the UF step (CF of $3.5 \times$ and $5 \times$ ), and the permeate and retentate produced at the end of the DF step ( 2 or $0.8 \mathrm{DV}$ ) were collected and frozen at $-18^{\circ} \mathrm{C}$ until analyzed.

\section{Cleaning Procedure}

At the end of each UF-DF experiment, the UF system was rinsed with tap water at $50^{\circ} \mathrm{C}$ for $2 \mathrm{~min}$ before measuring the water permeate flux for each membrane as described previously. After the rinsing step, an alkaline cleaning-in-place step was conducted at $\mathrm{pH} 10.5$ with Membrachlor 310 (Ecolab Inc.), followed by an acid cycle using citric acid solution at $0.1 \%$ (vol/vol; Ultrasil 76, Ecolab Inc.). The final cleaning stage was performed with Membrachlor 310 solution and chlorine (Chloreco, Ecolab Inc.) at concentration between 100 and $150 \mathrm{mg} /$ $\mathrm{kg}$ (Iodine-Chlorine test kit \#321). Between cleaning steps, the system was rinsed with tap water until reaching neutral $\mathrm{pH}$. Finally, UF membranes were stored at $4^{\circ} \mathrm{C}$ in an acid solution of $0.5 \%$ (vol/vol; Ultrasil MP, Ecolab Inc.) in between each use. The amount of water required for the cleaning step was equivalent for all 4 conditions.

\section{Chemical Analyses}

Total nitrogen content and NPN in samples were measured with the Kjeldahl method (AOAC International, 2000; methods 991.20 and 991.21). True protein (TP) was calculated by subtracting NPN from total nitrogen and multiplying by 6.38 . Total solids in the initial milks, permeates, and retentates were determined by the air drying method (AOAC International,
2000; method 990.20). Lactose content was determined by HPLC (ISO, 2007). Ash content was calculated by the difference.

\section{UF-DF Performance}

Permeate Flux. Permeate flow rate values were measured every 10 min throughout the experiment by weighing the permeate collected over $30 \mathrm{~s}$. Permeate flux $\left(J, \mathrm{~kg} / \mathrm{h} \cdot \mathrm{m}^{2}\right)$ values were calculated using Equation [1].

$$
J=\frac{V_{p}}{A},
$$

where $V_{p}$ is the permeate flow rate $(\mathrm{kg} / \mathrm{h})$ and $A$ is the membrane area $\left(\mathrm{m}^{2}\right)$.

Hydraulic Resistance. Membrane fouling was characterized using the resistance-in-series model according to the protocol detailed in Méthot-Hains et al. (2016) (Equation [2]).

$$
R_{\text {tot }}=R_{m}+R_{\text {rev }}+R_{i r r}
$$

where $R_{\text {tot }}$ is the total resistance $\left(\mathrm{m}^{-1}\right), R_{m}$ is the membrane resistance $\left(\mathrm{m}^{-1}\right), R_{\text {rev }}$ is the reversible resistance $\left(\mathrm{m}^{-1}\right)$, and $R_{i r r}$ is the irreversible resistance $\left(\mathrm{m}^{-1}\right) . R_{\text {rev }}$ refers to the casein micelle cake layer on the membrane surface, which can be removed by a rinsing step. $R_{\text {irr }}$ is caused by the adsorption of foulants onto the membrane, which can be eliminated by a cleaning-in-place protocol. $R_{m}$ refers to the inherent hydraulic resistance of the membrane.

Energy Consumption. Total energy consumption $(\mathrm{kWh})$ was calculated from voltage and amperage measurements made in situ using a voltmeter (model Fluke 3000FC, ON, Canada) and 3 ammeters (model Fluke A3100FC, ON, Canada) connected to the 3-phase asynchronous motor powering the system. Phase-to-phase voltage ( $U$, volts) and current $(I$, ampere) values were recorded every minute throughout each experiment. These values were used to determine the voltage and mean current for the duration of the process and the apparent power $(S)$, expressed as kilovolt-amperes (Equation [3]).

$$
S=\sqrt{3} \times U \times I .
$$

Apparent power values were used to determine the active power $(W)$ expressed in watts (Equation [4]).

$$
W=S \times \cos \phi
$$


where $\cos (\phi ; \%)$ is the power factor, which may vary depending on current measurement and the technical specifications of the equipment. Total energy consumption $\left(E_{\text {total }}\right)$, expressed in watt-hours $(\mathrm{Wh})$, was calculated using Equation [5]:

$$
E_{\text {total }}=\sum_{i} W_{i} \times \frac{\Delta t_{i}}{60}
$$

where $i$ is the number of time intervals, $W_{i}$ is the mean power input during the time interval, and $\Delta t_{i}$ is the duration of the time interval expressed in minutes.

Statistical Analysis. All experiments were performed in triplicate. Significant differences were analyzed by comparing means using the Bonferroni test $(P$ $\leq$ 0.05) with 13.0 JMP (SAS Institute Inc., Cary, NC).

\section{RESULTS}

\section{Permeate Flux}

Water flux characterization (data not shown) for the 10 and $50 \mathrm{kDa}$ UF membranes produced mean flux values of 342 and $447 \mathrm{~kg} / \mathrm{h} \cdot \mathrm{m}^{2}$, respectively, as deter- mined at $50^{\circ} \mathrm{C}$ and under a constant TMP of $465 \mathrm{kPa}$. Despite water flux values being higher for the $50 \mathrm{kDa}$ membrane, permeate fluxes were similar $(P>0.05)$ for all membrane MWCO used for UF-DF experiments. Consequently, an average of permeate flux at 10 and 50 $\mathrm{kDa}$ was calculated and only the evolution of permeate flux during UF-DF of pasteurized skim milk at $50^{\circ} \mathrm{C}$ for the 2 UF-DF sequences was presented in Figure 1. However, some differences were observed during the DF step (as a function of UF-DF sequence), which started at 130 and $154 \mathrm{~min}$ for the $3.5 \times-2 \mathrm{DV}$ and $5 \times-0.8 \mathrm{DV}$ sequences, respectively. Permeate flux values were significantly higher $(P<0.05)$ and constantly increased during $\mathrm{DF}$ for the $3.5 \times-2 \mathrm{DV}$ sequence (from $5.6 \pm 0.8$ to $8.7 \pm 0.8 \mathrm{~kg} / \mathrm{h} \cdot \mathrm{m}^{2}$ ) compared with DF $5 \times-0.8 \mathrm{DV}$ (from $3.2 \pm 0.2$ to $2.3 \pm 0.1 \mathrm{~kg} / \mathrm{h} \cdot \mathrm{m}^{2}$ ). Total flux decline reached $89 \%$ for the $5 \times-0.8 \mathrm{DV}$ sequence, compared with $58 \%$ for the $3.5 \times-2 \mathrm{DV}$ sequence.

\section{Retentate Composition}

Table 1 shows the composition of initial pasteurized skim milk and final retentate and permeate in terms of TS, TP, lactose, and mineral content. Because MWCO

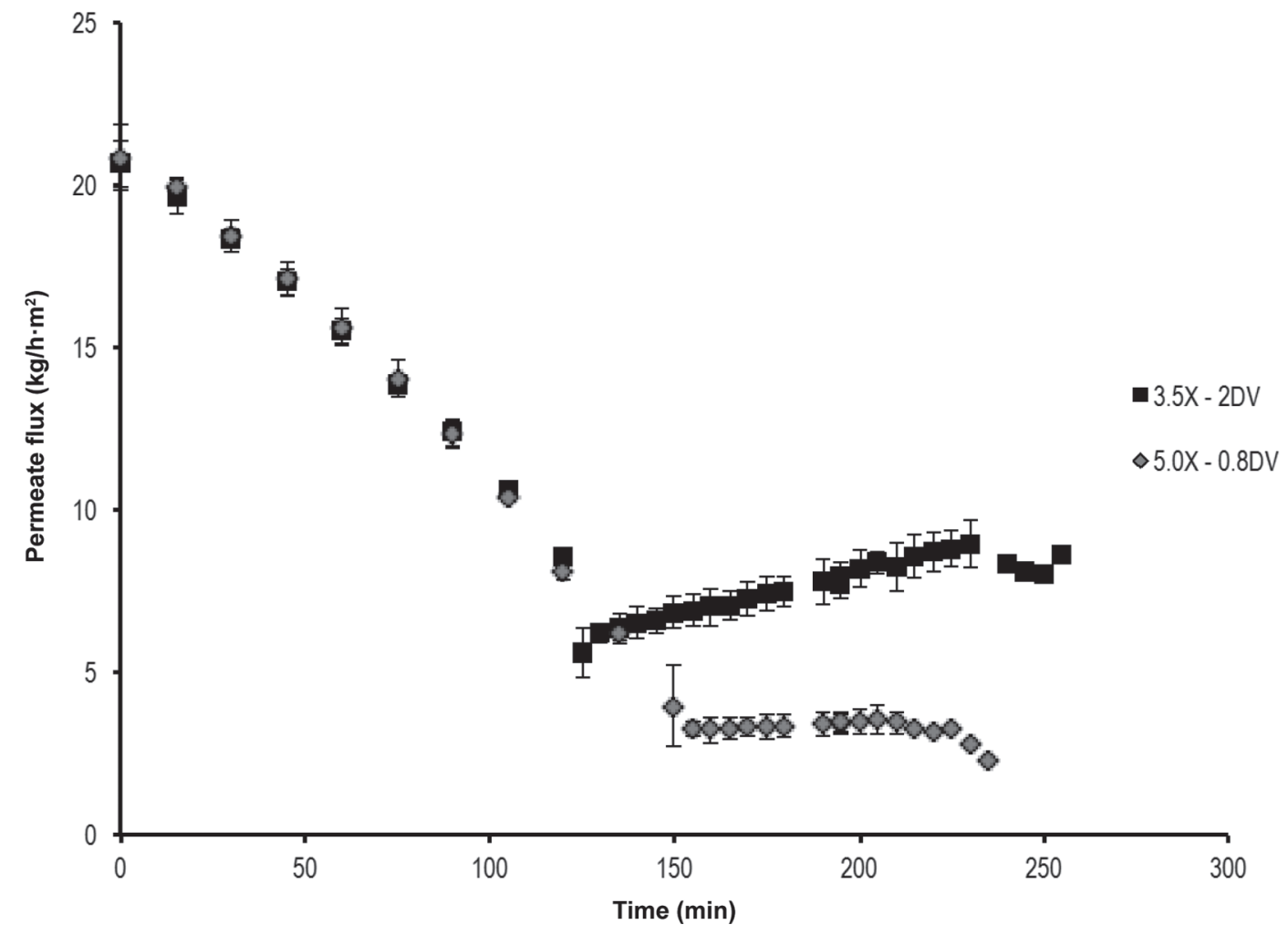

Figure 1. Evolution of mean permeate flux during UF-diafiltration (DF) of pasteurized skim milk (temperature $\left.=50^{\circ} \mathrm{C}\right)$ for 2 UF-DF sequences $[3.5 \times-2$ diavolumes (DV) and $5 \times-0.8 \mathrm{DV}]$. Because permeate fluxes were similar for all molecular weight cut-off (MWCO), an average of permeate flux at 10 and $50 \mathrm{kDa}$ is presented in this figure. Error bars represent $\mathrm{SD}$ of replicate determinations. 
had no significant effect $(P>0.05)$ on the composition of skim milk and UF retentates and permeates, the data were pooled in 2 groups $(3.5 \times-2 \mathrm{DV}$ and $5 \times-0.8 \mathrm{DV})$ to highlight the effect of the UF-DF sequence on composition. The TP content of the retentate was found to be similar for all UF-DF sequences, with values close to $80 \%$ dry weight. Total solids and ash content were higher in retentates obtained for the $5 \times-0.8 \mathrm{DV}$ sequence. Lactose content was similar for both UF-DF sequences in the final retentates $(0.4 \pm 0.1 \%$ for the $3.5 \times-2 \mathrm{DV}$ sequence and $0.5 \pm 0.1 \%$ for the $5 \times-0.8 \mathrm{DV}$ sequence) and in the UF permeates $(5.8 \pm 0.9 \%$ for the $3.5 \times-2 \mathrm{DV}$ sequence and $5.8 \pm 0.9 \%$ for the $5 \times-0.8 \mathrm{DV}$ sequence). A higher lactose content was obtained in the final DF permeates for the $5 \times-0.8 \mathrm{DV}$ sequence $(4.8 \pm$ $0.7 \%)$ than for the $3.5 \times-2 \mathrm{DV}$ sequence $(1.8 \pm 0.3 \%)$. Finally, relatively high values in true protein content $(0.5 \pm 0.1 \%$ and $0.6 \pm 0.1 \% \mathrm{wt} / \mathrm{vol})$ were obtained in both UF permeates. There are no definite explanations for these high values that may result from retentate leakage in the permeate compartment. However, no other experimental data in Table 1 can support this hypothesis.

\section{Hydraulic Resistance}

Table 2 reports the membrane resistance $\left(R_{m}\right)$, reversible $\left(R_{\text {rev }}\right)$, and irreversible $\left(R_{\text {irr }}\right)$ resistance, and total $\left(R_{t o t}\right)$ resistance for each UF-DF sequence carried out with 10 and $50 \mathrm{kDa}$ membrane pore sizes. The membrane MWCO affected resistance because $R_{m}$ was higher $(P<0.05)$ at $10 \mathrm{kDa}$ compared with $50 \mathrm{kDa}$. No significant differences $(P>0.05)$ were observed in $R_{\text {irr }}$ for different MWCO and UF-DF sequences. The $R_{\text {rev }}$ was also similar for the $5 \times-0.8 \mathrm{DV}$ sequence, whatever the MWCO. However, the $5 \times-0.8 \mathrm{DV}$ sequence induced a drastic increase in $R_{\text {rev }}$ compared with the $3.5 \times-2 \mathrm{DV}$ sequence (3.5- and 3.81-fold higher for the 10 and 50 $\mathrm{kDa}$ MWCO membranes, respectively). Overall, $R_{\text {rev }}$ made the biggest contribution to the total resistance, accounting for between 81 and $96 \%$ of the total. This observation must however be carefully interpreted because there was no recirculation loop in the UF-system to maintain high crossflow velocity.

\section{Specific Energy Consumption and Overall Performance}

Figure 2 shows the specific energy consumption, calculated as $\mathrm{kWh} / \mathrm{kg}$ lactose removed from feed, for both UF-DF sequences $(3.5 \times-2 \mathrm{DV}$ and $5 \times-0.8 \mathrm{DV})$. Because MWCO had no significant effect on the specific energy consumption for each UF-DF sequence, the data were pooled in 2 groups corresponding to the 2 UF-DF se-

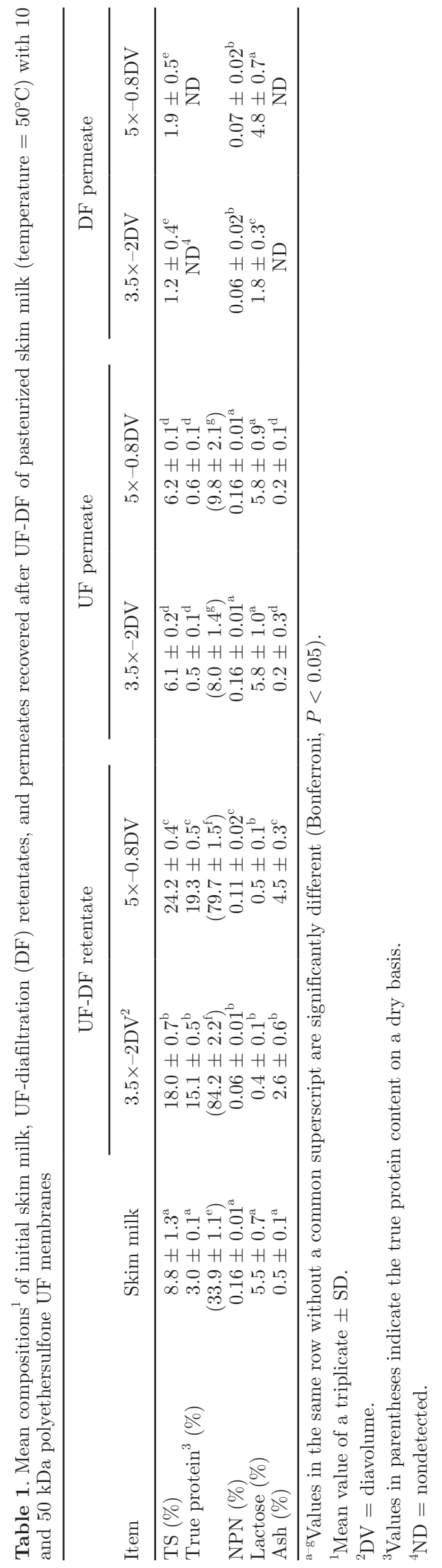


Table 2. Hydraulic resistance after UF-diafiltration $(\mathrm{DF})$ of pasteurized skim milk (temperature $\left.=50^{\circ} \mathrm{C}\right)$ with 10 and $50 \mathrm{kDa}$ polyethersulfone UF membranes ${ }^{1}$

\begin{tabular}{lccccc}
\hline & \multicolumn{2}{c}{$10 \mathrm{kDa}$} & & \multicolumn{2}{c}{$50 \mathrm{kDa}$} \\
\cline { 2 - 3 } \cline { 5 - 6 } Resistance $\left(\mathrm{m}^{-1}\right)$ & $3.5 \times-2 \mathrm{DV}$ & $5 \times-0.8 \mathrm{DV}$ & & $3.5 \times-2 \mathrm{DV}$ & $5 \times-0.8 \mathrm{DV}$ \\
\hline$R_{m}\left(\times 10^{13}\right)$ & $0.93 \pm 0.05^{\mathrm{a}}$ & $0.93 \pm 0.04^{\mathrm{a}}$ & & $0.76 \pm 0.02^{\mathrm{b}}$ & $0.76 \pm 0.03^{\mathrm{b}}$ \\
$R_{\text {irr }}\left(\times 10^{13}\right)$ & $5.0 \pm 0.5^{\mathrm{a}}$ & $5.3 \pm 0.3^{\mathrm{a}}$ & & $3.9 \pm 0.7^{\mathrm{a}}$ & $3.8 \pm 0.6^{\mathrm{a}}$ \\
$R_{\text {rev }}\left(\times 10^{13}\right)$ & $24.4 \pm 1.9^{\mathrm{a}}$ & $85.4 \pm 8.2^{\mathrm{b}}$ & & $30.0 \pm 1.4^{\mathrm{c}}$ & $114.1 \pm 22.7^{\mathrm{b}}$ \\
$R_{\text {tot }}\left(\times 10^{13}\right)$ & $30.3 \pm 1.4^{\mathrm{a}}$ & $91.6 \pm 8.0^{\mathrm{b}}$ & & $34.6 \pm 2.1^{\mathrm{a}}$ & $118.7 \pm 22.9^{\mathrm{b}}$ \\
\hline
\end{tabular}

${ }^{\mathrm{a}-\mathrm{c}}$ Values in the same row without a common superscript are significantly different (Bonferroni, $\left.P<0.05\right)$.

${ }^{1} \mathrm{DV}=$ diavolume.

quences. During the UF-DF process, lactose is mainly removed at the UF step. For the $3.5 \times-2.0 \mathrm{DV}$ condition in our experiments, for each kilogram of lactose withdrawn from the feed, $85 \%$ was removed during the UF step, compared with $15 \%$ at the DF step. For the $5 \times-0.8 \mathrm{DV}$ condition, $93 \%$ of the lactose was removed during the UF step, compared with $7 \%$ during the DF step. Consequently, despite the similarity in global specific energy consumption $(P>0.05)$, the value of this indicator was higher $(P<0.05)$ during the DF step for the $3.5 \times-2 \mathrm{DV}$ sequence $(0.42 \pm 0.01$ and $0.47 \pm$ $0.01 \mathrm{kWh} / \mathrm{kg}$ of lactose removed) compared with the $5 \times-0.8 \mathrm{DV}$ sequence $(0.24 \pm 0.01$ and $0.25 \pm 0.01 \mathrm{kWh} /$ $\mathrm{kg}$ of lactose removed). Therefore, despite leading to better permeate fluxes, the DF step of the $3.5 \times-2 \mathrm{DV}$ sequence lasted longer because of the larger volume of tap water required, which significantly affected specific energy consumption values.

\section{DISCUSSION}

\section{Effect of the UF MWCO}

Our results showed that MWCO (10 vs. $50 \mathrm{kDa})$ had no effect $(P>0.05)$ on permeate flux for the same UFDF sequence. As mentioned by $\mathrm{Hu}$ and Dickson (2015), UF membranes are typically characterized by a large pore size distribution. The proportion of larger pores has the most significant effect on the evolution of permeate flux values over time, as the flux is very sensitive

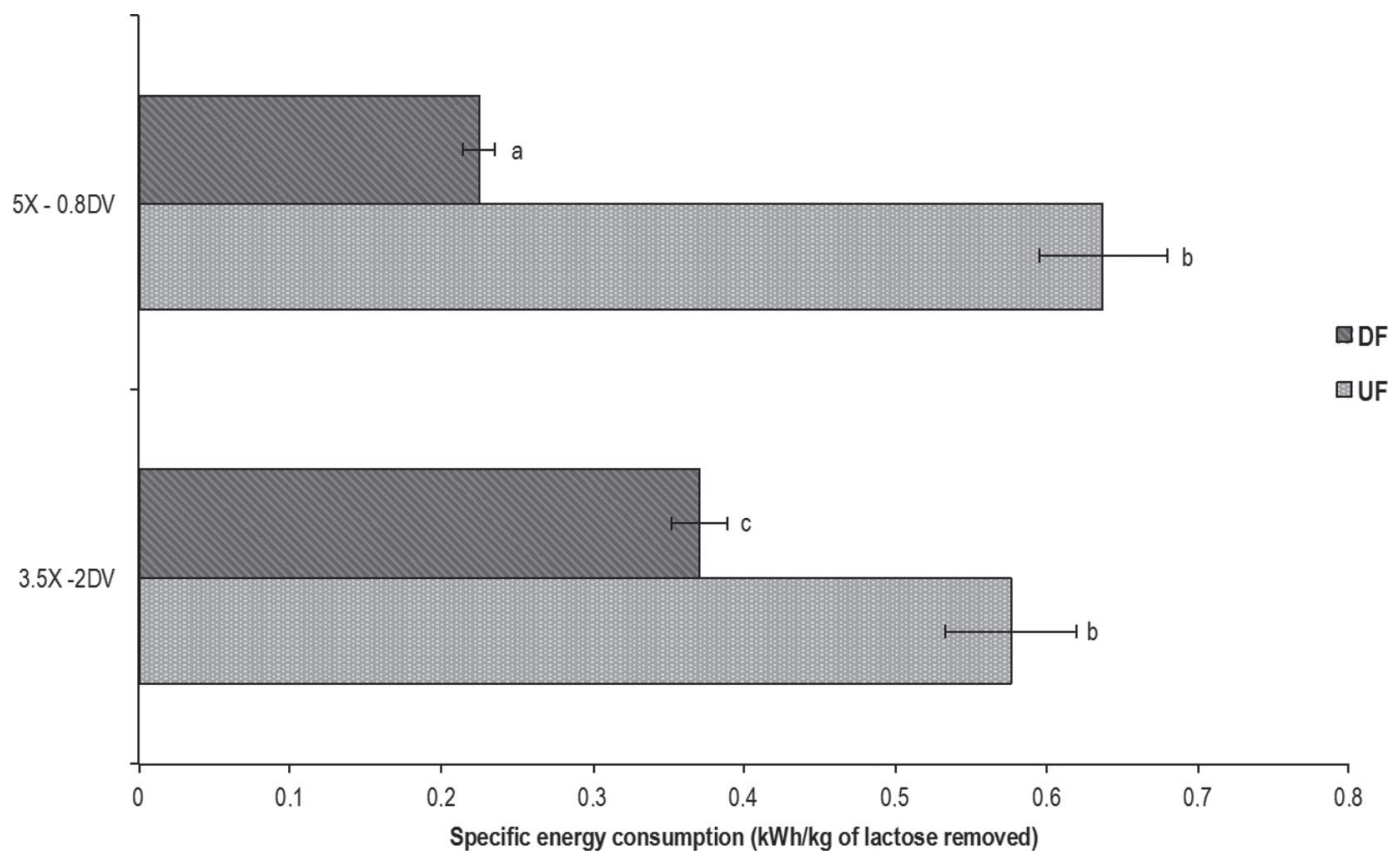

Figure 2. Specific energy consumption $(\mathrm{kWh} / \mathrm{kg}$ of lactose removed) during UF-diafiltration (DF) of pasteurized skim milk (temperature $=$ $50^{\circ} \mathrm{C}$ ) with polyethersulfone UF membranes. DV = diavolume. Error bars indicate SD of replicate determinations. Values without a common letter $(\mathrm{a}-\mathrm{c})$ are significantly different (Bonferroni, $P<0.05)$. 
to the obstruction of large pores by feed components (Hu and Dickson, 2015). These results are consistent with those obtained by Meireles et al. (1991), who reported similar behavior with pure solutions of BSA, ovalbumin, and $\beta$-LG. The authors reported that the pore size distribution for the $10 \mathrm{kDa}$ membrane was not altered during UF, in contrast to 40 and $100 \mathrm{kDa} \mathrm{UF}$ membranes whose pore size distribution was reduced. They proposed that the deposit enforces its selectivity in cases where the pore size of the deposit is smaller than that of the membrane (Meireles et al., 1991). A similar trend could occur during UF of milk.

Consequently, the selection of a $10-\mathrm{kDa}$ UF membrane seems justifiable for producing high milk protein concentrates. The use of a UF membrane having MWCO greater than $50 \mathrm{kDa}$ to improve permeate fluxes could eventually result in a decrease in protein rejection and losses of valuable milk protein. Conversely, a UF membrane having a pore size smaller than $5 \mathrm{kDa}$ may reduce the efficiency of the process by lowering membrane permeability and reducing lactose transmission (Hu and Dickson, 2015).

\section{Effect of the UF-DF Sequence}

For both membrane MWCO, the average permeate flux was similar $(P>0.05)$ during UF for all UF-DF sequences. The average permeate flux during DF was significantly higher $(P<0.05$; approximately 2.30 fold) and constantly increased during the $3.5 \times-2 \mathrm{DV}$ sequence. Two different phenomena explain flux decline during UF: (1) the adsorption of milk components at the surface and onto the membrane, and (2) the formation of a cake at the membrane surface. Flux decline and fouling during the preparation of high-milk-protein concentrates have been studied in the scientific literature and $\mathrm{Li}$ et al. (2017) suggest that the fouling mechanism in UF and UF-DF of concentrated milk is not purely cake formation or protein deposition, but a combination of both, influenced by operating conditions and evolution of the feed composition (Li et al., 2017). However, the work of Li et al. (2017) supports that the fouling mechanism in UF-DF of milk involves, more significantly, cake formation of casein micelles. This filter cake forms on the membrane surface in the first minute of the filtration process and acts as a dynamic membrane controlling the permeate flux for the rest of the UF-DF process. The higher flux values obtained with the $3.5 \times-2 \mathrm{DV}$ scenario could be related to both a thinning of the concentration polarization layer at the membrane surface when a larger DF volume is used and a decrease in the solution viscosity when adding water to the feed.
The resistance data showed that reversible resistance was higher $(P<0.05)$ for the $5 \times-0.8 \mathrm{DV}$ sequence for all MWCO, which also supports the assumption of a thicker concentration polarization layer at $\mathrm{CF} 5 \times$. Irreversible resistance was similar $(P>0.05)$ for both sequences, whatever the MWCO, which suggests that milk component deposition within the pores is similar for all conditions $(P>0.05)$. Increasing the crossflow velocity may be an alternative to help reduce the membrane polarization layer (Marshall et al., 1993).

The TS and ash contents of the retentates were higher $(P<0.05)$ for the $5 \times-0.8 \mathrm{DV}$ sequence, largely due to the lower number of DV during DF (smaller purification step). These results are consistent with the higher reversible resistance values for the $5 \times-0.8 \mathrm{DV}$ sequence, as the dynamic cake layer formed during concentration and the high viscosity of the feed could act as barriers to the particles. Similar values for the lactose content of the retentates were obtained for both UF-DF sequences $(0.41 \pm 0.08$ vs. $0.52 \pm 0.13)$. The calculation of lactose removal (data not shown) also provides similar values: $99 \%$ for both sequences. Given these results, it would be better to push the UF step to $5 \times$ or beyond, which would achieve a similar degree of lactose removal while requiring a smaller DF step.

Finally, although the compositional differences observed between the 2 retentates seem relatively minor, these should be taken into account because it is well known that ash and lactose content of WPC can have a significant effect on their functionality (de Boer, 2014).

\section{Energy Requirements}

As shown in Figure 2, the pumping energy consumption required to remove $1 \mathrm{~kg}$ of lactose from the feed was higher $(P<0.05)$ at the DF step for the $3.5 \times-2 \mathrm{DV}$ sequence. Indeed, despite having better permeation fluxes, the $3.5 \times \mathrm{DF}$ step lasted longer because of the larger volume of tap water required. However, energy consumption might be underestimated because the energy required to maintain the fluid at $50^{\circ} \mathrm{C}$ was not included in the calculation. Overall, a smaller DF step contributes to higher efficiency in terms of specific energy consumption.

\section{Overall Performance of the 2 UF-DF Sequences in a Model Dairy Plant}

Table 3 shows data from a simulation for the production of high milk protein concentrates in a model dairy plant processing $1,500 \times 10^{3} \mathrm{~kg}$ of skim milk in $20 \mathrm{~h}$, sequentially [i.e., a concentration step (UF) followed by a purification step (DF)]. Experimental flux values 
Table 3. Comparison of the overall performance of the 2 UF-diafiltration (DF) sequences $[3.5 \times-2$ diavolumes $(\mathrm{DV})$ and $5 \times-0.8 \mathrm{DV}]$ conducted in a model dairy plant processing $1,500 \times 10^{3} \mathrm{~kg}$ of skim milk in $20 \mathrm{~h}$

\begin{tabular}{|c|c|c|c|}
\hline Item & & $3.5 \times-2 \mathrm{DV}$ & $5 \times-0.8 \mathrm{DV}$ \\
\hline Input & Quantity of water required for DF $\left(\times 10^{3} \mathrm{~kg}\right)$ & 870.7 & 242.7 \\
\hline \multirow{2}{*}{ Output } & Generated mass of permeate (UF) $\left(\times 10^{3} \mathrm{~kg}\right)$ & 1,102 & 1,234 \\
\hline & Total generated mass of permeate (UF-DF; $\times 10^{3} \mathrm{~kg}$ ) & 1,973 & 1,476 \\
\hline \multirow[t]{2}{*}{ Hydraulic performances } & UF permeate flux at $\mathrm{VCF}^{1}=3.5$ or $5.0\left(\mathrm{~kg} / \mathrm{h} \cdot \mathrm{m}^{2}\right)$ & 8.5 & 4.0 \\
\hline & Mean DF permeate flux $\left(\mathrm{kg} / \mathrm{h} \cdot \mathrm{m}^{2}\right)$ & 7.5 & 3.3 \\
\hline Energy requirements & Energy consumption during UF-DF $\left(\times 10^{3} \mathrm{kWh}\right)$ & 114 & 111 \\
\hline Membrane requirements & Membrane surface $\left(\mathrm{m}^{2}\right)$ & 12,288 & 19,250 \\
\hline \multirow[t]{5}{*}{ Global performance indicators } & Duration UF step (h) & 10.5 & 16.2 \\
\hline & Duration DF step (h) & 9.5 & 3.8 \\
\hline & Total protein generated per $\mathrm{kg}$ of milk $(\%)$ & 3.2 & 3.2 \\
\hline & Energy consumption per $\mathrm{kg}$ of protein generated $\left(\mathrm{kWh} \cdot \mathrm{kg}^{-1}\right)$ & 2.3 & 2.2 \\
\hline & Water consumption per $\mathrm{kg}$ of protein generated $(\mathrm{kg} / \mathrm{kg})$ & 17.2 & 4.8 \\
\hline
\end{tabular}

${ }^{1} \mathrm{VCF}=$ volumetric concentration factor.

were used as part of this simulation and we assumed that both $\mathrm{CF}$ were reachable in a single-stage model.

Membrane Area Requirements. To determine the required membrane area for each UF-DF scenario, experimental permeate flux values were used to express the evolution of the number of DV as a function of the installed membrane area when processing $1,500 \mathrm{~m}^{3}$ sequentially in $20 \mathrm{~h}$. From these relations, it was possible to determine the approximate membrane area required for the desired number of DV and the exact surface was obtained by iterations on the membrane area. Calculations showed that $12,288 \mathrm{~m}^{2}$ and $19,250 \mathrm{~m}^{2}$ were required to sequentially concentrate and diafiltrate $1,500 \mathrm{~m}^{3}$ of skim milk in $20 \mathrm{~h}$ for the $3.5 \times-2 \mathrm{DV}$ and the $5 \times-0.8 \mathrm{DV}$ sequences, respectively. Consequently, the $5 \times-0.8 \mathrm{DV}$ sequence requires $57 \%$ more membrane area than the $3.5 \times-2 \mathrm{DV}$ to process the same volume of skim milk in $20 \mathrm{~h}$.

Processing Time and Energy Consumption. The permeate flow rate $\left(\mathrm{kg} \cdot \mathrm{h}^{-1}\right)$ was obtained by multiplying the experimental UF flux $\left(\mathrm{kg} \cdot \mathrm{h}^{-1} \cdot \mathrm{m}^{-2}\right)$ by the hypothetical membrane surface area. The data for the retentate flow rate $\left(\mathrm{kg} \cdot \mathrm{h}^{-1}\right)$ were obtained by dividing the calculated permeate flow rate by $(\mathrm{CF}-1)$, then multiplying the result by the ratio of the retentate density at $50^{\circ} \mathrm{C}$ to the permeate density at $50^{\circ} \mathrm{C}$. Adding permeate mass flow to retentate mass flow allowed for the determination of the milk flow rate $\left(\mathrm{kg} \cdot \mathrm{h}^{-1}\right)$ for both scenarios. Flow rate values were required to calculate the duration of the UF step (h), which was obtained by dividing the initial mass of milk entering the system by the milk flow rate.

Concentration step takes $52 \%$ of the process duration in the $3.5 \times-2 \mathrm{DV}$ sequence, whereas it takes $81 \%$ of the $20 \mathrm{~h}$ process length in the $5 \times-0.8 \mathrm{DV}$ sequence. The smaller number of DV and the lower volume of retentate to diafiltrate in the second sequence explain why the DF step takes $60 \%$ less time.

The pumping energy requirements were estimated for the UF, DF, and total processes. Our experimental energy consumption data (expressed as $\mathrm{Wh} / \mathrm{kg}$ of retentate) were used for these calculations. The $5 \times-0.8 \mathrm{DV}$ sequence required more energy for UF ( 75 vs. $61 \times 10^{3}$ $\mathrm{kWh}$ ), whereas the $3.5 \times-2 \mathrm{DV}$ sequence required more energy for DF ( 53 vs. $36 \times 10^{3} \mathrm{kWh}$ ). However, the total energy consumption (UF-DF) was similar for the $3.5 \times-2 \mathrm{DV}$ and for the $5 \times-0.8 \mathrm{DV}$ processes (114 vs. $\left.111 \times 10^{3} \mathrm{kWh}\right)$. Accordingly, the energy consumption per $\mathrm{kg}$ of protein generated $\left(\mathrm{kWh} \cdot \mathrm{kg}^{-1}\right)$ was similar for both sequences.

Water Consumption and Generated Volumes of Co-products. The mass of permeate generated (kg) was obtained by multiplying the permeate flow rate $\left(\mathrm{kg} \cdot \mathrm{h}^{-1}\right)$ by the duration of the UF step $(\mathrm{h})$. The water flow rate $\left(\mathrm{kg} \cdot \mathrm{h}^{-1}\right)$ was calculated by multiplying the average DF flux $\left(\mathrm{kg} \cdot \mathrm{h}^{-1} \cdot \mathrm{m}^{-2}\right)$ by the membrane surface area. The DF water volume was determined multiplying the water flow rate by the duration of the DF step (h).

Results obtained from the simulation indicate that a greater mass of permeate would be generated during UF-DF by the $3.5 \times-2 \mathrm{DV}$ sequence (1 973 vs. 1 $476 \times 10^{3} \mathrm{~kg}$ of permeate). This volume of permeate would have to be subsequently treated to recover the lactose and mineral content, in addition to being cooled down to $4^{\circ} \mathrm{C}$ and stored. The water consumption expressed per kilogram of protein generated (\%) supports the same conclusion because a higher ratio was ob- 
tained for the $3.5 \times-2 \mathrm{DV}$ sequence compared with the $5 \times-0.8 \mathrm{DV}$ sequence $(17.2$ vs. $4.8 \mathrm{~kg} / \mathrm{kg}$ ). Reducing the water consumption of the DF process is important for process efficiency. Counter-current DF, which suggests the recycling of UF, nanofiltration, or reverse osmosis permeates, represents an alternative to classical DF. However, it would require larger membrane areas in dairy plants (Barba et al., 2000; Lipnizki and Madsen, 2002). Similarly, Foley (2006) studied the possibility of combining UF with variable-volume $\mathrm{DF}$, which consists of adding water at a lower rate than the permeation flux, concentrating the solution simultaneously with purification by DF. This technique could reduce water consumption without significantly increasing the total process time.

Overall, the present simulation shows that, despite similar total energy requirements, the 2 different UFDF sequences have a direct effect on water consumption required to perform DF and on the amount of effluent (by-products) to process. However, perhaps the most important economic impact of UF-DF sequence is on membrane area $\left(\mathrm{m}^{2}\right)$ required to perform protein concentration from the same amount of milk over the same operating period: the $5 \times-0.8 \mathrm{DV}$ sequence will require $57 \%$ more membrane area than the $3.5 \times-2 \mathrm{DV}$. As pointed out by Mercier-Bouchard et al. (2017), cleaning and maintenance costs of membrane systems are a direct function of the membrane area installed in a plant. It must also be considered that this simulation assumes equal membrane lifetime (typically $18 \mathrm{mo}$ ), which may not prove to be true between the 2 UF-DF sequences.

\section{CONCLUSIONS}

This study revealed differences between both UF-DF sequences in terms of permeation flux values during the DF step, water consumption, and volumes of permeate generated during the process. The $3.5 \times-2 \mathrm{DV}$ sequence resulted in higher permeation flux values but required a larger volume of water for DF and generated a larger volume of permeate, which could lead to a greater environmental impact. When scaling up to industrial production volumes, results however show that UF-DF sequence selection has a direct effect on membrane area $\left(\mathrm{m}^{2}\right)$ required to perform protein concentration. These results are based on extrapolation and simplified assumptions, so a comparative life cycle assessment is needed to determine the optimal UF-DF sequence in terms of environmental footprint. However, this study represents a good first step in creating a comprehensive decision-making tool for dairy processors producing high-milk-protein concentrates.

\section{ACKNOWLEDGMENTS}

This work was supported by the Natural Sciences and Engineering Research Council of Canada and Novalait Inc. The authors thank Diane Gagnon, Mélanie Martineau, and Pascal Lavoie from the Department of Food Science at Laval University for their technical assistance with experiments and analysis.

\section{REFERENCES}

Adams, M. C., J. Zulewska, and D. M. Barbano. 2013. Effect of annatto addition and bleaching treatments on ultrafiltration flux during production of $80 \%$ whey protein concentrate and $80 \%$ serum protein concentrate. J. Dairy Sci. 96:2035-2047.

AOAC International. 2000. Official Methods of Analysis. 17th ed AOAC Int., Gaithersburg, MD.

Asbi, B. A., and M. Cheryan. 1992. Optimizing process time for ultrafiltration and diafiltration. Desalination 86:49-62.

Bacchin, P., P. Aimar, and R. W. Field. 2006. Critical and sustainable fluxes: Theory, experiments and applications. J. Membr. Sci. 281:42-69.

Barba, D., F. Beolchini, and F. Veglió. 2000. Minimizing water use in diafiltration of whey protein concentrates. Sep. Sci. Technol. 35:951-965.

Bazinet, L., and F. Castaigne. 2011. Concepts de Génie Alimentaire - Procédés Associés et Applications À La Conservation Des Aliments. Éditions T., Paris, France.

Cheryan, M. 1998. Ultrafiltration and Microfiltration Handbook. 2nd ed. CRC Press, ed. Technomic Publishing Company Inc., Lancaster, PA.

de Boer, R. 2014. From Milk By-Products to Milk Ingredients: Upgrading the Cycle. John Wiley \& Sons, Ltd., Wageningen, the Netherlands.

Foley, G. 2006. Ultrafiltration with variable volume diafiltration: A novel approach to water saving in diafiltration processes. Desalination 196:160-163.

Govindasamy-Lucey, S., J. J. Jaeggi, M. E. Johnson, T. Wang, and J. A. Lucey. 2005. Use of cold ultrafiltered retentates for standardization of milks for pizza cheese: Impact on yield and functionality. Int. Dairy J. 15:941-955.

Guinee, T. P., B. T. O'Kennedy, and P. M. Kelly. 2006. Effect of milk protein standardization using different methods on the composition and yields of Cheddar cheese. J. Dairy Sci. 89:468-482.

Heino, A., J. Uusi-Rauva, and M. Outinen. 2010. Pre-treatment methods of Edam cheese milk. Effect on cheese yield and quality. Lebensm. Wiss. Technol. 43:640-646.

Hu, K., and J. Dickson, ed. 2015. Membrane Processing for Dairy Ingredient Separation. IFT Press, Wiley-Blackwell, Hoboken, NJ.

ISO. 2007. Standard ISO 22662:2007 (IDF 198:2007)-Milk and milk products - Determination of lactose content by high-performance liquid chromatography (Reference method). International Organization for Standardization (ISO), Geneva, Switzerland.

Lapointe-Vignola, C. F., and Fondation de Technologie Laitière du Québec Inc. 2002. Science et Technologie Du Lait: Transformation Du Lait. Presses Int. Polytechnique, ed. Montréal, QC, Canada.

Li, H., Y. Hsu, Z. Zhang, N. Dharsana, Y. Ye, and V. Chen. 2017. The influence of milk components on the performance of ultrafiltration/diafiltration of concentrated skim milk. Sep. Sci. Technol. 52:381-391.

Lipnizki, F., and R. F. Madsen. 2002. Concepts of industrial-scale diafiltration systems. Desalination 144:179-184.

Marshall, A. D., P. A. Munro, and G. Trsgkdh. 1993. The effect of protein fouling in microfiltration and ultrafiltration on permeate flux, protein retention and selectivity: A literature review. Desalination 91:65-108. 
Meireles, M., P. Aimar, and V. Sanchez. 1991. Effects of protein fouling on the apparent pore size distribution of sieving membranes. J. Membr. Sci. 56:13-28.

Meireles, M., A. Bessieres, I. Rogissart, P. Aimar, and V. Sanchez. 1995. An appropriate molecular size parameter for porous membranes calibration. J. Membr. Sci. 103:105-115.

Mercier-Bouchard, D., S. Benoit, A. Doyen, M. Britten, and Y. Pouliot. 2017. Process efficiency of casein separation from milk using polymeric spiral-wound microfiltration membranes. J. Dairy Sci. 100:8838-8848.

Méthot-Hains, S., S. Benoit, C. Bouchard, A. Doyen, L. Bazinet, and Y. Pouliot. 2016. Effect of transmembrane pressure control on energy efficiency during skim milk concentration by ultrafiltration at 10 and $50^{\circ}$ C. J. Dairy Sci. 99:8655-8664.

Meyer, P., A. Mayer, and U. Kulozik. 2015. High concentration of skim milk proteins by ultrafiltration: Characterisation of a dy- namic membrane system with a rotating membrane in comparison with a spiral wound membrane. Int. Dairy J. 51:75-83.

Ng, K. S. Y., M. Haribabu, D. J. E. Harvie, D. E. Dunstan, and G. J. O. Martin. 2017. Mechanisms of flux decline in skim milk ultrafiltration: A review. J. Membr. Sci. 523:144-162.

Pouliot, Y. 2008. Membrane processes in dairy technology-From a simple idea to worldwide panacea. Int. Dairy J. 18:735-740.

Rinaldoni, A. N., C. C. Tarazaga, M. E. Campderrós, and A. P. Padilla. 2009. Assessing performance of skim milk ultrafiltration by using technical parameters. J. Food Eng. 92:226-232.

Rosenberg, M. 1995. Current and future applications for membrane processes in the dairy industry. Trends Food Sci. Technol. 6:12-19.

Shi, X., G. Tal, N. P. Hankins, and V. Gitis. 2014. Fouling and cleaning of ultrafiltration membranes: A review. J. Water Process Eng. $1: 121-138$ 